\title{
DIREITO PRIVADO E DEMOCRACIA: ORIGENS GREGAS DO SISTEMA REGISTRAL IMOBILIÁRIO BRASILEIRO
}

\author{
Tiago Seixas Themudo \\ Centro Universitário 7 de Setembro (UNI7), Ceará \\ tiago.themudo@uni7.edu.br
}

\author{
Andrea Sales Santiago Schmidt \\ Universidade Portucalense, Portugal \\ andreasantiago85@yahoo.com.br
}

\begin{abstract}
RESUMO: É objetivo deste trabalho analisar o sistema de registro de imóveis no Brasil, cujo fim precípuo é a garantia da publicidade, enquanto princípio democrático, dos negócios jurídicos. Essa preocupação com a publicidade remonta à Grécia Antiga, de forma que nas diversas cidades havia mecanismos que tornavam as negociações envolvendo imóveis conhecidas por todos. Inclusive, estabeleceu-se, no sistema grego, os livros fundiários, para as inscrições dos negócios envolvendo propriedade imóvel. Sendo assim, poder-se-ia afirmar, a partir da análise das formas de publicidade e do sistema de hipotecas existentes na Grécia Antiga, que o sistema registral imobiliário brasileiro possui origens helênicas, e não romanas? Para responder a esta questão foram analisadas referências da historiografia jurídica greco-romana, bem como as obras da escola francesa de história do direito privado grego e romano. Para o estabelecimento das relações entre os fatos jurídicos e o contexto social, político e econômico, foram seguidos os preceitos metodológicos da historiografia contemporânea. Contribui-se, desta maneira, à reflexão histórica sobre o direito privado no ocidente e sua relação com as democracias gregas, incrementando o capital intelectual do campo jurídico brasileiro e, consequentemente, nossa criatividade institucional, indispensável em tempos de transformações rápidas e profundas.
\end{abstract}

PALAVRAS-CHAVE: Direito privado grego. Direito de Propriedade. Imóveis. Publicidade.

\section{Private law and democracy: Greek origins of the Brazilian real estate registration system}

\begin{abstract}
The objective of this work is to analyze the property registration system in Brazil, whose primary purpose is to guarantee advertising, as a democratic principle, of legal businesses. This concern with advertising goes back to Ancient Greece, so that in the different cities there were mechanisms that made the negotiations involving real estate known to everyone. In fact, in the Greek system, land books were established for the registration of businesses involving immovable property. So, could it be said, from the analysis of the forms of advertising and the mortgage system existing in Ancient Greece, that the Brazilian real estate registration system has Hellenic origins, and not Roman ones? To this end, references from Greco-Roman legal historiography were analyzed, as well as the works of the French school of history of Greek and Roman private law. To establish the relationship between the legal facts and the social, political and economic context, the methodological precepts of contemporary historiography were followed. In this way, it contributes to the historical reflection on private law in the West and its relationship with Greeks democracies, increasing the intellectual capital of the Brazilian legal field and, consequently, our institutional creativity, indispensable in times of rapid and profound transformations.
\end{abstract}

KEYWORDS: Greek private law. Property right. Property. Publicity. 


\section{INTRODUÇÃO}

O Registro de Imóveis é, no Brasil, a peça fundamental da Publicidade Imobiliária. Tem, desde 1865, o condão de transmitir o domínio sobre bens imóveis nos atos entre vivos, e é, também, essencial à constituição dos ônus reais. O sistema registral brasileiro tem por objetivos principais a publicidade e, consequentemente, a segurança jurídica. Por sua importância para o crédito e para a segurança da propriedade, é relevante o conhecimento do histórico da publicidade na Antiguidade, época em que o sistema adotado na Grécia mereceu grande destaque pelo estágio avançado em que se encontrava.

Por meio da pesquisa histórica, busca-se compreender, em que medida, a publicidade imobiliária no Brasil pode ser compreendida como uma das heranças do direito privado grego, relevando a intima articulação deste dispositivo jurídico com as democracias helênicas dos sécs. V e IV a.c. Para tanto, inicia-se com o histórico da publicidade nas compras e vendas de imóveis, bem como na instituição de hipotecas na Grécia Antiga. Então, a seguir, passa-se propriamente ao tema central, ou seja, as bases gregas do sistema registral imobiliário no Brasil, com destaque para a publicidade e para os livros de registros de imóveis.

Para o desenvolvimento dessa pesquisa, utilizou-se o método dedutivo, posto que se partiu de uma hipótese sobre o funcionamento e a característica do fenômeno em estudo, qual seja, investigar como e em que medida a publicidade do direito grego relaciona-se com a publicidade no sistema de registros imobiliários no Brasil. Adotou-se a natureza teórica da pesquisa, com a utilização de fontes bibliográficas, dentre essas, livros e periódicos. Quanto aos resultados, a metodologia da pesquisa foi de caráter puro, pois teve como finalidade expor como e em que medida o sistema registral imobiliário brasileiro tem influência do Direito Grego do período democrático.

\section{A PUBLICIDADE COMO DISPOSITIVO DEMOCRÁTICO NAS TRANSA- ÇÕES IMOBILIÁRIAS NO DIREITO CIVIL GREGO}

A publicidade, que hoje é princípio basilar dos principais sistemas registrais imobiliários, não é criação moderna, ao contrário, na Grécia Antiga foi umas das principais preocupações nas transações envolvendo imóveis, fosse de compra e venda ou de instituição de ônus reais. Esta preocupação advinha de um princípio mais abrangente que impunha a publicidade a todos os atos do poder, com o intuito de estabelecer um espaço de plano transparência em oposição ao ambiente de sigilo e exclusividade do governo aristocrático. O sistema da pólis, conceito elaborado por Jean-Pierre Vernant para descrever a estrutura democrática grega, estava apoiado nos princípio da linguagem, entendida enquanto debate público do contraditório, da isonomia cívica e da pleno publicidade dos atos do poder, fosse ele legislativo ou jurídico, haja vista a ausência de um poder executivo nas democracias gregas da antiguidade clássica. ${ }^{1}$

A aplicação do princípio da publicidade, filho legítimo da tradição democrática grega, fora aplicado não apenas na esfera do direito público, mas também, e de maneira integral, ao direito privado. Ainda causa certa estranheza referenciar a tradição jurídica ocidental, sobretudo o direito provado, à herança helênica. No entanto, parte da prosperidade econômica e hegemônica política dos gregos está diretamente ligada ao grau de evolução e complexidade que conferiram aos dispositivos jurídicos que regulavam as relações entre os particulares, nas áreas da

1 VERNANT, Jean-Pierre. As origens do pensamento grego. Rio de Janeiro: Ed. Bertrand Brasil, 1992. 
família, propriedade e obrigações. A regulação dos processos de alienação fundiária não constituía exceção ${ }^{2}$.

Em fragmentos da obra de Teofrasto ${ }^{3}$ é possível identificar várias formas e modos de publicidade, que variavam de acordo com as cidades, embora a finalidade fosse sempre a mesma: tornar públicas e cognoscíveis a todos as transações envolvendo imóveis. Do fragmento da obra de Teofrasto, extrai-se o seguinte sobre a publicidade nas diversas cidades da Grécia Antiga ${ }^{4}$ :

Certas legislações querem que as vendas sejam proclamadas por um arauto público e que sejam anunciadas com vários dias de antecedência; outras exigem que estas ocorram perante um magistrado. Assim, a lei de Pittacos ordena que a venda seja realizada perante um magistrado. Há as que prescrevem que a venda seja publicada no local onde tem sede o magistrado por ao menos sessenta dias, como em Atenas, e que o comprador pague a centésima parte do preço, para liberar-se de todo aquele que possa vir a reclamar ou discutir seu direito, e que se saiba pelo pagamento do preço quem é o justo adquirente. Em outras, ainda, as vendas devem ser anunciadas durante cinco dias consecutivos antes de confirmadas, com escopo de dar aos interessados o tempo para intervir e reclamar a propriedade ou a casa. Tais são as leis de Cízico. Os túranos suprimiram todas estas formalidades e não publicam as vendas ou outros atos em praça pública, mas obrigam vendedor e adquirente a reunirem-se e dar a três dos vizinhos mais próximos uma pequena moeda, como memória e testemunho do fato. Com isso, os magistrados, em um caso, e os vizinhos, no outro, são responsabilizados ao se negarem a receber, ou ao receberem duas vezes da mesma pessoa, ou, ainda, se, havendo recebido, se negam a indicar o nome do comprador. Ademais, não convém esquecer que os anúncios, proclamações, e tudo que envolver as oposições, não são, na maior parte dos casos, senão expedientes empregados para remediar a ausência de outra norma. Com efeito, em todos os lugares onde está estabelecida a inscrição das propriedades e dos contratos, é fácil saber por ela se os bens são livres e sem ônus, e se o vendedor é realmente proprietário porque o magistrado inscreve imediatamente o comprador no lugar do vendedor. Como por vezes existem terceiros que se passam por compradores e vendedores, convém que existam normas sobre este particular. Existe em algumas cidades previsões para evitar estes abusos, e, ao mesmo tempo, para assegurar a publicidade do direito de propriedade. Segundo tais normas, aquele que compra uma casa deve sacrificar sobre o altar de Apolo que preside o distrito, e aquele que compra um campo deve sacrificar na cidade que mora, e jurar perante o magistrado encarregado da inscrição, e três moradores da cidade, que adquiriu justamente, sem fraude, simulação, ou vício de qualquer ordem. O vendedor deve jurar da mesma maneira, que vende sem dolo. Quem não residir na cidade, deve sacrificar e prestar juramento sobre o altar de Júpiter Agoraios. Os necessitados podem livrar-se do juramento com uma oferenda de perfumes. Na falta destas formalidades, o magistrado nega a inscrição".

A publicidade nas transações imobiliárias, portanto, estava disseminada no mundo grego, sendo umas das principais preocupações daquele povo, que enxergava nela a possibilidade de evitar fraudes. Pozo ${ }^{5}$, em defesa desta ideia, mostra que mesmo em tratados internacionais a publicidade era trazida à baila, citando o primeiro tratado entre romanos e cartagineses, no qual se dava garantia pública aos créditos de comerciantes contratados por arauto ou perante registrador; ainda, que em um trecho do retórico e filósofo cínico Dion Crisóstomo, se chamava a atenção às operações contratadas "em público", as quais punham "a cidade como testemunha".

2 MELO, Alisson, THEMUDO, Tiago. A poligamia no direito privado ateniense e as relações paralelas no direito civil brasileiro no século XXI: aproximações jurídicas. Revista Argumentum, v. 18, n. 3, p. 817-842, set-dez. 2017.

3 Teofrasto viveu entre 372 e 288 a.C., e produziu a obra "Tratado sobre as leis", que não existe mais na íntegra. A conservação do fragmento que trata das transmissões imobiliárias se deve ao antologista do século $\mathrm{V}$ d.C. Ioannes Stobaeus, que reuniu em uma mesma obra trechos educativos oriundos da literatura grega.

4 Cf. POZO, L. La propriedad inmueble y el registro de la propriedad en el Egipto faraónico. Madrid, Colégio de Registradores de la Propriedad y Mercantiles de Espana, s.d., p. 155-157 (tradução livre dos autores).

5 Cf. POZO, L. La propriedad inmueble y el registro de la propriedad en el Egipto faraónico. Madrid, Colégio de Registradores de la Propriedad y Mercantiles de Espana, s.d., p. 159-160). Tradução livre. 
Inicialmente, interessa-nos a publicidade na compra e venda de imóveis. Segundo Teofrasto, em algumas cidades, ela era garantida pela assistência de um arauto público, que deveria anunciar a venda, por várias vezes, como pressuposto de cognoscibilidade de toda a comunidade.

Em Cízico, na Ásia Menor, assim como em outras cidades que Teofrasto não nos indica, a venda só era perfeita, e o comprador só se tornava proprietário incomutável, depois de proclamações públicas realizadas durante cinco dias seguidos e destinadas a colocar aqueles com direito real sobre a coisa vendida em condições de tomarem conhecimento. ${ }^{6}$

Em outras cidades, mediante a participação de três vizinhos do imóvel transacionado, que iriam assistir à venda e que em troca lhes era rendida uma moeda "em memória e em testemunho do ato"7. Em conceito atual, pode-se identificar esses vizinhos como confrontantes do imóvel. Convém anotar que na legislação brasileira vigente, por vezes encontramos a necessidade de participação desses confrontantes nos procedimentos registrais, a exemplo da retificação imobiliária, em que a lei impõe a assinatura dos confrontantes do imóvel a ser retificado na planta e no memorial descritivo feito pelos profissionais legalmente habilitados. Esse é o teor do artigo $213, \S 2^{\circ}$ :

\begin{abstract}
Se a planta não contiver a assinatura de algum confrontante, este será notificado pelo Oficial de Registro de Imóveis competente, a requerimento do interessado, para se manifestar em quinze dias, promovendo-se a notificação pessoalmente ou pelo correio, com aviso de recebimento, ou, ainda, por solicitação do Oficial de Registro de Imóveis, pelo Oficial de Registro de Títulos e Documentos da comarca da situação do imóvel ou do domicílio de quem deva recebê-la.
\end{abstract}

A preocupação dos gregos com a publicidade e a clareza das transações imobiliárias era tamanha que nessas cidades onde se estabelecia a participação das testemunhas, não se tratavam de quaisquer pessoas ou de quem chegasse primeiro ao local da venda, mas sim dos próprios vizinhos do imóvel transacionado, por ser mais fácil encontrá-los quando houvesse necessidade de seus testemunhos ${ }^{8}$. De uma forma menos comum, havia o sistema de publicidade pela participação de um magistrado, que deveria estar presente no ato da compra e venda do imóvel.

Em outra passagem, Teofrasto indica uma forma muito peculiar de publicidade, que provavelmente era praticado em Enos, uma antiga cidade da Trácia. Segundo a lei daquele local, aqueles que desejassem adquirir uma propriedade imóvel deveriam oferecer um sacrifício sobre o altar de Apolo. Caso a propriedade fosse rural e adquirida para a moradia do comprador, deste ato solene deveriam participar comprador, vendedor, três habitantes do lugar e a pessoa encarregada do registro. Além do sacrifício, eram feitos juramentos pelo comprador e pelo vendedor de que estavam contratando sem incidência de fraude.

Caso o imóvel transacionado fosse adquirido para ser alugado depois, o sacrifício seria destinado a Zeus Agoraios, e não a Apolo. Esse ritual não tinha apenas o fim de publicidade, mas também era forma de evitar compra e venda simuladas. Não se pode perder de vista que na Grécia Antiga, os deuses eram as autoridades máximas. Daí explica-se a solenidade do ritual de sacrifícios e a seriedade que o ato representa. O temor reverencial, certamente, seria o principal mecanismo de combate às fraudes. Enquanto não houvesse o sacrifício, a compra e venda não poderia ser registrada pelos magistrados, que se comprometiam, previamente, para o exercício

6 BEAUCHET, Ludovic. Histoire du droit privé de la république athénienne. 1897, p. 325. (Tradução livre dos autores).

7 BEAUCHET, Ludovic. Histoire du droit privée de la République athénienne. v. 3. Paris: Librairie Marescq Ainé, 1897, p. 327.

8 THEMUDO, Tiago, PASCARELLI, Adriano. O princípio da publicidade e o problema da transmissão da propriedade no direito privado grego. Revista Jurídica da UNI7. v. 14. n. 2, p. 31-41, 2017. 
da função, em jamais registrar uma venda antes de receber das partes o juramento previsto na lei ${ }^{9}$.

Em outras cidades, a exemplo de Atenas, a publicidade consistia na afixação de cartazes em locais públicos, com inscrições sobre quadros brancos, ou sobre placas de madeira revestidas de giz, em que havia a identificação sucinta da propriedade e os nomes das partes envolvidas.

Certamente, a forma mais avançada de publicidade na Grécia Antiga encontra-se nos livros de registros fundiários que noticia Teofrasto e, felizmente, alguns de seus fragmentos chegaram até nossos tempos. Tratava-se de livros de registro das transações imobiliárias, que de suas características podemos afirmar quase absoluta coincidência com os nossos atuais livros de registro geral de imóveis ${ }^{10}$. Esses livros fundiários, existentes em Éfeso, Turi, Rodes, Tinos e em outras cidades, encerravam as transcrições de contratos que tivessem por objeto as transmissões de propriedade, e onde se descobria se os bens eram livres e sem ônus, bem como se pertenciam ao vendedor.

\begin{abstract}
Ter-se-ia, aqui a chamada "anagrafé", que se dividia em dois momentos: um primeiro, consistente em uma proclamação mediante exposição do documento, dando a todos conhecimento de um certo direito real imobiliário. Seria um substituto da "katagrafé" já mencionada. E em um segundo momento, em que o documento era conservado em um ofício ou por uma magistratura especializada em documentos de transferências imobiliárias. Isto era feito em tábuas, ou pergaminhos. A origem do ofício possivelmente está no costume de se depositar uma cópia do contrato em poder de um terceiro imparcial, em quem as partes confiam, de forma que, a partir de então, o instrumento não mais possa ser alterado. Com isso, com o tempo surgem magistrados especializados nesta função ${ }^{11}$.
\end{abstract}

Os registros fundiários, portanto, representavam um sistema completo de publicidade para a transmissão das propriedades, não sendo mero repositório de informações cadastrais. Sobre o fragmento encontrado, eram anotados os nomes do arconte, do mês e do calendário; o extrato dos atos; o preço da venda; os nomes do vendedor e do comprador; a propriedade; as pessoas intervenientes no negócio celebrado. Esses livros ficavam sob a guarda de magistrados especiais, os mnemônicos, que possivelmente estavam presentes em quase toda a Grécia, como faz supor passagem da obra de Aristóteles, que ressalta a importância de suas funções. Vê-se, portanto, que na Grécia se encontrava muito desenvolvido o conceito da publicidade das alienações, uma vez que, nas várias partes do país, a venda não existia independentemente de certas formalidades mais ou menos solenes ${ }^{12}$.

O anagrafe, que consistia na inscrição da compra e venda nos livros fundiários, certamente era o sistema de publicidade mais perfeito. $\mathrm{O}$ sentido jurídico da publicidade podia ser entendido sobre três ângulos diferentes. Em primeiro lugar, a publicidade se opunha à clandestinidade, no sentido de evitar a fraude, pois o negócio desenvolvia-se às claras, sob o amparo do Direito. Em segundo lugar, a publicidade significava publicação, ou seja, forma de tornar o negócio conhecido por todos, o que permitia qualquer tipo de impugnação de terceiros que poderiam eventualmente ser afetados pelo negócio realizado. E pela terceira dimensão da publicidade, ter-se-ia certa garantia de compromisso com a boa-fé do ato perante a comunidade, os deuses, as

9 THEMUDO, PASCARELLI. O princípio da publicidade e o problema da transmissão da propriedade no direito privado grego, op., cit., 2017.

${ }^{10}$ No Brasil, as compras e vendas são registradas no Livro 2 dos Cartórios de Registro de Imóveis, sendo alguns dos seus requisitos: a data; o resumo do título (valor da compra, forma de pagamento); qualificação completa do vendedor e do comprador e indicação precisa do imóvel.

${ }^{11}$ Cf. POZO, L. La propriedad inmueble y el registro de la propriedad en el Egipto faraónico. Madrid, Colégio de Registradores de la Propriedad y Mercantiles de Espana, s.d., p. 170-172. (Tradução livre dos autores).

${ }^{12}$ LUZZATI, I. Della trascrizione: commento teorico-pratico al titolo XXII, libro III del códice civile italiano. v. 1, 4 ed. Turim: Utet, 1905, p. LIV. 
autoridades públicas, de forma que todos eram, de alguma forma, garantes do êxito da transmissão do imóvel que ocorria com o conhecimento de todos.

Além dos efeitos próprios da publicidade, o registro dos contratos de compra e venda de imóveis, segundo alguns pesquisadores, era também requisito essencial para a própria transmissão da propriedade ${ }^{13}$. Teofrasto, em sua obra, consignou que os imóveis eram transferidos pelo contrato, pelo pagamento do preço e pelas formalidades legais, a exemplo do registro ${ }^{14}$. Para alguns estudiosos, o sistema de transmissão imobiliária na Grécia Antiga era consensual, ou seja, bastaria o próprio contrato para que se efetuasse a transferência da propriedade dos imóveis.

Dareste, contudo, baseado na afirmação de Teofrasto, foi o primeiro a defender que a propriedade somente se transferia com o registro, cogitando-se de um verdadeiro efeito constitutivo. Segundo esse autor, em Atenas, assim como ocorre atualmente, o consentimento das partes, expresso no contrato, garantia os direitos obrigacionais entre as partes, mas a propriedade somente se transferia efetivamente após o pagamento do preço e do registro ${ }^{15}$. Em uma carta dirigida a Caillemer ${ }^{16}$, o autor deixou claro o seu entendimento, aduzindo que "em Atenas, a propriedade não se transfere senão depois de cumpridas as formalidades de publicidade" 17 .

Nesse mesmo sentido, tem-se o discurso do orador com pseudônimo de "Demóstenes" que trata de uma situação em que havia a necessidade de se provar que Protos, seu cliente, era o proprietário de um barco. Não havia dúvida de que ele era o possuidor, mas haviam suscitado dúvidas se ele seria o verdadeiro proprietário. Para defender a propriedade de seu cliente, Demóstenes valeu-se de três premissas: que Protos era quem tinha comprado o barco; que a coisa estava registrada em seu nome no ofício público; e que havia pago o preço ${ }^{18}$. Desta forma, a inscrição das convenções particulares nos livros de registros consistia em forma eficiente de publicidade, além de ser requisito para transmissão da propriedade.

Outra característica singular do registro nos livros fundiários era o efeito de veracidade e de autenticidade dos registros, que segundo Louis Gernet ${ }^{19}$, uma vez feito o registro, não seria mais possível invalidar os seus efeitos, quer se tratasse de uma venda, ou de uma retirada de ônus sobre o imóvel ou ainda de uma doação.

\subsection{A publicidade das hipotecas}

A preocupação com a publicidade na Grécia Antiga não se restringia às compras e vendas, mas também aos ônus reais que incidiam sobre os imóveis, em especial, a hipoteca. À semelhança dos sistemas de publicidade nas compras e vendas, o das hipotecas também não era uniforme, variando de acordo com os locais. Segundo Teofrasto, em certas cidades, a exemplo de

\footnotetext{
13 THEMUDO, PASCARELLI. O princípio da publicidade e o problema da transmissão da propriedade no direito privado grego, op. cit., 2017.

${ }^{14}$ POZO, L. La propriedad inmueble y el registro de la propriedad en el Egipto faraónico. Madrid: Colégio de Registradores de la Propriedad y Mercantiles de Espana, s/d.

15 DARESTE, Rodolphe. En Revue de Législation Ancienne el Moderne Francaise et Etrangère, 1870-1871.

${ }^{16}$ Carta de 9 de novembro de 1871 citada em nota por Caillemer, na Revue de Législation Ancienne et Moderne Francaise el Etrangère, 1870-1871, p. 635.

${ }^{17}$ DARESTE, Rodolphe. En Revue de Législation Ancienne el Moderne Francaise et Etrangère, 1870-1871, p. 262.

${ }^{18}$ ZENOTH, C. Le contrat de vente en droit grec classique les obligations des parties. In: Rev. Int. Dr. Ant., Tomo II, 1953.

${ }^{19}$ Cit., 1964.
} 
Cízico, a constituição das hipotecas deveria ser anunciada publicamente por um arauto durante cinco dias seguidos, a fim de possibilitar oposição por terceiros interessados ${ }^{20}$.

Em outras localidades, em que havia os livros fundiários, a exemplo de Tinos, a hipoteca era inscrita juntamente com o registro da propriedade, de forma que da consulta ao assento, terse-ia tanto as informações sobre o comprador, o vendedor, as características da propriedade, como também sobre os ônus que recaíam sobre o imóvel. A utilidade desses registros como forma de publicidade foi exposta por Teofrasto, para quem "Em todos os lugares onde está estabelecida a inscrição das propriedades e dos contratos, é fácil saber se os bens estão livres e sem multas, e se o vendedor é realmente proprietário" 21.

Em Atenas, as hipotecas eram registradas através de marcos físicos sobre os imóveis, que eram chamados de "orós". Em grandes peças de pedra, mármore ou madeira, as estelas, eram inscritas as garantias hipotecárias, com a indicação da natureza do imóvel, o nome do credor e a soma de dinheiro garantida pelo bem. Em geral, colocava-se apenas um orós no imóvel hipotecado, mas se o mesmo imóvel fosse objeto de garantia de várias dívidas, nada impedia que fossem justapostos vários oróis, como forma de publicidade real e de maior segurança. Para alguns autores, estaria aqui demonstrado que a publicidade das hipotecas tem início na Grécia do séc. VI a. $\mathrm{C}^{22}$.

Os oróis continham, de maneira geral, todas as indicações necessárias sobre as cargas hipotecárias que recaíam sobre o imóvel. Como não havia uma lei uniforme que estabelecesse os requisitos que deveriam ser observados nos "oróis", esses variavam de acordo com os costumes de cada lugar. Beauchet relata as diversas menções encontradas nos oróis que chegaram até nós: a indicação de que a pedra ou a placa é um óros; a designação do imóvel hipotecado; o nome do credor; a natureza da dívida garantida pela hipoteca; o nome do devedor; o montante da dívida garantida pela inscrição; a data da constituição da hipoteca.

Vê-se, portanto, o quão avançado era o sistema de inscrição das garantias hipotecárias helênico, que além de forma de publicidade, era um sistema indubitavelmente designado a evitar fraudes, haja vista o princípio jurídico da isonomia que garantia a tutela do Estado ao interesse de terceiros não implicados diretamente na transação fiduciária. Através de uma consulta aos livros fundiários, ou da simples visita ao imóvel, seria possível a qualquer interessado conhecer a "história" da propriedade, em especial se, sobre a mesma, recaíam direitos de terceiros, a exemplo das garantias imobiliárias.

\section{ORIGEM GREGA DO SISTEMA REGISTRAL DE IMÓVEIS NO BRASIL}

O registro de imóveis no Brasil é atividade essencialmente pública, desenvolvida por particulares através da delegação obtida mediante aprovação em concurso público de provas e títulos. O registrador é um profissional do direito, dotado de fé pública e que deve prestar os serviços a seu cargo de forma adequada, de acordo com o cumprimento rigoroso dos deveres próprios da delegação pública em que está investido, sob pena, inclusive, de perda dessa delegação. A atividade é exercida de forma privada, contudo, sobre fiscalização direta e imediata do Poder Judiciário, na esfera local, através do juiz corregedor de registros públicos e, na esfera estadual, pela Corregedoria Geral de Justiça.

${ }^{20}$ BEAUCHET. Hist. cit., 1897.

${ }^{21}$ BEAUCHET. Hist. cit., 1897, p. 327-328.

${ }^{22}$ LUZZATI, I. Della trascrizione: commento teorico-pratico al titolo XXII, libro III del códice civile italiano. v. 1, 4 ed. Turim: Utet, 1905, p. LIV. 
A Constituição de 1988 estabeleceu uma nova ordem jurídica às atividades do registro de imóveis, explicitando sua natureza e o caráter privado $^{23}$, reforçando a busca pela eficiência na sua prestação, bem como o aprimoramento e a maior exigência das habilidades técnico-profissionais. Antes da promulgação dessa Carta Magna, o serviço de registros públicos no país era prestado por pessoas designadas pelos governantes, sem qualquer critério objetivo, sem exigência de prévia qualificação e, em sua maioria, era transferido entre parentes, como uma espécie de "atividade herdada".

A Constituição Federal moralizou a prestação dessa atividade pública essencial à segurança dos negócios jurídicos ao estabelecer a necessidade de aprovação em concurso público para o recebimento da outorga de delegação, erradicando-se, paulatinamente, parte de um passado comprometido por interesses de cunho patrimonialista e clientelista: a distribuição política das titularidades das serventias extrajudiciais, os institutos da vitaliciedade e hereditariedade compulsórias, bem como, o amadorismo em termos de conhecimentos técnico-jurídicos dos profissionais ${ }^{24}$. A atividade registral imobiliária no Brasil é regulamentada pela Lei $\mathrm{n}^{\circ}$ 6.015, de 1973.

\subsection{A publicidade imobiliária como fundamento democrático do sistema registral no Brasil}

O sistema registral de imóveis é mecanismo de publicidade imobiliária, através do qual se publicizam os direitos reais sobre imóveis, tornando de conhecimento amplo a realidade fática e jurídica sobre determinado bem. Tem-se, aqui, a primeira base grega do registro de imóveis brasileiro.

Segundo a Lei Federal 8.935/93 que regulamenta os serviços notariais e registrais no país, a publicidade é um dos objetivos fundamentais do sistema de registros. Nesse sentido: “Art. $1^{\circ}$ Serviços notariais e de registro são os de organização técnica e administrativa destinados a garantir a publicidade, autenticidade, segurança e eficácia dos atos jurídicos".

A publicidade registral pode ser definida como a garantia das informações inscritas no livro público, tanto em relação ao imóvel e direitos sobre ele incidentes, quanto sobre as pessoas que constam como proprietárias deles. Manifesta-se, ainda, a publicidade, pelo fornecimento de informações e certidões pelos serviços de imóveis a qualquer pessoa que as requeira, independentemente de demonstração de interesse jurídico.

É praxe nas transações imobiliárias que a parte compradora ou a credora de ônus reais requeira a apresentação da certidão atualizada da matricula para a concretização do negócio, demonstrando-se a confiança nas informações contidas nos livros de registros de imóveis, sendo exemplo de manifestação da publicidade registral enquanto garantidora da segurança dos negócios jurídicos, logo, fomentadora da geração e circulação de riquezas.

O objetivo do registo de imóveis é que "qualquer comprador em potencial de terra registrada deve sempre ser capaz de verificar, através de um simples exame do registro, a natureza exata de todos os interesses existentes em ou sobre a terra que ele propõe comprar". Percebe-se,

${ }^{23}$ BRASIL. Constituição Federal de 1988. “Art. 236. Os serviços notariais e de registro são exercidos em caráter privado, por delegação do Poder Público".

24 ARAÚJO FILHO, Clarindo Ferreira. Constitucionalização das atividades notarial e de registro e a relação entre o princípio da eficiência e a responsabilidade civil. Dissertação (Mestrado Acadêmico em Direito Constitucional). Instituto Brasiliense de Direito Público, Brasília: IBDP, 2011. 
portanto, a imbricada relação entre a publicidade no registro de imóveis e a preocupação em evitar fraudes, à medida em que a informação clara acerca da realidade jurídica do imóvel é imprescindível para a segurança dos negócios jurídicos. ${ }^{25}$

Nesse sentido, "esta publicidade ainda mais energicamente reclama a segurança dos interesses ligados à propriedade - é ela necessária para prevenir as fraudes que a má-fé de uns protegida pela clandestinidade pudera preparar em prejuízo da boa-fé de outros". ${ }^{26}$ Era exatamente o que acontecia na Grécia Antiga, conforme ensinou Teofrasto "as menções do registro permitem ver, primeiro, se o bem pertence ao alienador e, segundo, se há multas reais sendo cobradas" 27 .

O sistema brasileiro, a exemplo do que existia na Grécia, tem uma forma muito avançada de publicidade, sendo essa uma de suas principais características. Em razão disso, trata-se um sistema bastante seguro, em especial, no que concerne às hipotecas, que devem ser necessariamente inscritas no livro 2 de registros de imóveis, à margem da matrícula, justamente para que seja oponível a todos ${ }^{28}$.

A ausência de publicidade completa pode ter reflexos negativos diretos na economia de um país, foi o que aconteceu na França, por exemplo, em que para se compensar o alto risco do empréstimo de dinheiro sem a certeza e a segurança do adimplemento das dívidas, os bancos estabeleciam juros exorbitantes, até que em 1836, um deputado francês chamado Lavielle declarou que a revisão dos títulos hipotecários não poderia ocorrer sem a aplicação irrestrita da publicidade $^{29}$. Intensas foram as discussões até que em 1855 publicou-se uma nova lei hipotecária, que determinava a aplicação, com rigor, da especialidade da hipoteca e de todos os mecanismos que prezassem pela publicidade.

Os Estados Unidos também sofreram graves danos em sua economia pela ausência de publicidade dos registros de hipotecas, pois as instituições financeiras concediam os créditos imobiliários, mas sem ter a certeza da disponibilidade do imóvel. Diante da insolvência dos devedores e da insuficiência dos imóveis em garantir o pagamento das dívidas é que os bancos quebraram, o que deu início à profunda crise daquele país em 2008.

\subsection{O livro de registro geral de imóveis como a segunda base grega do sistema brasileiro}

A Lei $n^{\circ} 6015 / 1973^{30}$ aperfeiçoou e dinamizou o sistema registral imobiliário brasileiro e introduziu o sistema de matrículas dos imóveis. A cada imóvel atribuiu-se um número próprio, chamado de matrícula, que tem por vigas mestres os princípios da unicidade e da concentração. A partir do imóvel devidamente matriculado é que se registram ou se averbam os elementos negociais que forem ocorrendo, conforme o caso. A matrícula, portanto, é o "espelho" do imóvel, nela são inscritas todas as modificações jurídico-reais pelas quais passa o bem durante sua existência histórica.

\footnotetext{
${ }^{25}$ GRAY, Kevin; GRAY, Susan. Elements of land law. 5.ed. London: OUP, 2008, p. 38.

${ }^{26}$ PEREIRA, Lafayette. Direito das coisas. Rio de Janeiro: Freitas Bastos, 1956, p. 27.

${ }^{27}$ BEAUCHET. Hist, cit., 1897, p. 331.

28 BRASIL. Lei Federal 6015/1973. "Art. 167 - No Registro de Imóveis, além da matrícula, serão feitos. I - o registro: 2) das hipotecas legais, judiciais e convencionais".

${ }^{29}$ LAGO, Ivan Jacopetti do. História da publicidade imobiliária no Brasil. Dissertação (Mestrado em Direito) - Faculdade de Direito da Universidade de São Paulo. 133f. São Paulo, 2008.

${ }^{30}$ BRASIL. Lei Federal 6.015, de 31 de dezembro de 1973. Dispõe sobre os registros públicos, e dá outras providências.
} 
Os elementos essenciais da matrícula são a descrição e a individualização do imóvel; a identificação e a qualificação do proprietário; a informação da inscrição anterior que lhe deu origem. Para fins de matrícula e de registro de imóveis, a regra é a inscrição por extrato do título, ou seja, uma inscrição resumida, em que o oficial extrai do título apresentado, após a sua qualificação, os elementos que a lei impõe, ao invés de se proceder à sua trasladação integral. Na qualificação do título, o registrador de imóveis verifica a disponibilidade do bem, a propriedade do vendedor/devedor, a forma do título, a compatibilidade com a lei, dentre outros critérios que conferem segurança ao registro.

É possível afirmar que a qualificação registral também existia no sistema grego, através da análise do discurso Pro Flacco, de Cícero, que relata o caso de um romano chamado Décranus, que desejoso de se apropriar dos bens de duas mulheres de Pérgamo, fez de Polemócrates, seu cúmplice, tutor de ambas, e comprou dele, em nome de suas pupilas, e por um preço irrisório, os bens que almejava ${ }^{31}$.

Mas essas vendas foram acusadas de fraudulentas por um certo Dion, sem dúvida um parente das duas mulheres. A instância, dirigida contra Polemócrates, foi levada diante dos juízes gregos de Apolônia que, julgando segundo a lei grega, condenaram Polemócrates a reparações civis, e anularam, consequentemente, os atos de venda, assim como as transcrições que Décranus fizera. Apesar dos juízes de Apolônia terem anulado a transcrição feita na cidade, Décranus, querendo renovar a formalidade, se dirigiu à cidade de Pérgamo, capital judiciária da região a qual pertencia Apolônia na intenção de inscrever novamente o negócio imobiliário, mas o magistrado encarregado da transcrição recusou-se a registrar um título manifestadamente nulo ${ }^{32}$.

Em relação aos livros fundiários, a exemplo do que existia em Tinos, vê-se absoluta coincidência com os livros de registro de imóveis como os conhecemos hoje $\mathrm{e}^{33}$.

\begin{abstract}
Em Tinos, e é provável que fosse assim em várias outras cidades, existia, portanto, um sistema completo de publicidade para a transmissão das propriedades seja a título oneroso, seja a título gratuito. Toda alienação era submetida à formalidade que Teofrasto chama de anagrafe, expressão traduzida geralmente por transcrição, pois é quase idêntica à nossa transcrição moderna. Os registros onde eram mencionadas as vendas e as constituições de dote eram mantidos, muito provavelmente, pelos astinomos, magistrados encarregados da polícia urbana e da estrada. No registro, eram cuidadosamente anotados o nome do arconte, o nome do mês e do calendário. $\mathrm{O}$ extrato dos atos nele inseridos era redigido seguindo uma fórmula mais ou menos uniforme e mencionando, quando se tratava de uma venda, o imóvel vendido, sua situação, o preço da venda, o vendedor e o comprador - e, na ocasião, o estabelecimento da propriedade, - o sinal pago sobre o preço, as pessoas participantes da venda, seja para dar sua autorização, para consentir, seja para garantir o contrato.
\end{abstract}

Segundo a lei federal brasileira, são requisitos dos registros: “Art. 176, II ${ }^{34}, 1$ ) a data; 2) o nome, domicílio e nacionalidade do transmitente, ou do devedor, e do adquirente, ou credor, bem como; 3) o título da transmissão ou do ônus; 4) a forma do título, sua procedência e caracterização; 5) o valor do contrato, da coisa ou da dívida, prazo desta, condições e mais especificações, inclusive os juros, se houver.

E todos esses elementos já existiam nos livros fundiários na Grécia Antiga, como forma de publicidade das transações imobiliárias. Inclusive, conforme defendia Dareste, que foi exposto no item 1, o registro naquela época seria constitutivo, o que também ocorre no Brasil, em

${ }^{31}$ CICERO, M. Tullius. The Orations of Marcus Tullius Cicero. London: Henry G. Bohn, 1856.

32 THEMUDO, PASCARELLI. Princíp. cit., 2017.

${ }^{33}$ Beauchet, L. Histoire du droit privée de la République athénienne. v. 3 1987, p. 328). Tradução livre dos autores.

34 BRASIL. Constituição (1988). Constituição da República Federativa do Brasil. Brasília, DF: Senado Federal, 1988. 
que somente se transfere propriedade imóvel através do registro em cartório. Na Grécia, os livros ficavam sob a guarda de um magistrado especial, que exerciam uma função do Estado, assim como ocorre no Brasil, em que os registradores de imóveis são delegatários do poder público.

\section{Conclusão}

O nosso sistema registral imobiliário, embora comumente dito de origem romana, encontra na Grécia o início de sua genealogia, assim como boa parte do direito privado ocidental, aqui entendido como uma das contribuições mais importantes do espírito helênico, e um dos pilares de sua democracia. Um dos objetivos essenciais da atividade registral no Brasil é garantir a publicidade dos negócios imobiliários, seja através do próprio registro, seja através do fornecimento de certidões, que permitem a qualquer pessoa conhecer a situação dos bens, tais como sua disponibilidade, a quem pertence, se existem ônus reais, dentre outros elementos. A razão prática desta atividade é garantir a existência de um mecanismo institucional para a prevenção de fraudes e respeito ao direito de terceiros.

Na Grécia Antiga havia uma grande preocupação com a publicidade das transações imobiliárias, tanto de compra e venda, como de hipotecas, o que não era conhecido com tanta perfeição no sistema romano. Pode-se concluir, portanto, que uma das bases dos registros de imóveis no Brasil, a publicidade, certamente é de origem grega. Inclusive, os próprios livros de registro, como os conhecemos hoje, já existiam naquela sociedade antiga.

No contexto da pós-modernidade, o registro de imóveis no Brasil tem passado por profundas transformações, em especial, a instituição de um sistema de registro eletrônico, com o paulatino abandono do uso de papeis e a inclusão dos atos registrais em uma plataforma digital, em busca da universalização das atividades de registro público imobiliário.

A interconexão de todas as unidades do serviço de registro de imóveis é o objetivo primordial do sistema registral do século XXI, em que a interoperabilidade das bases de dados amplia o acesso aos serviços de expedição de certidões e de informações de qualquer imóvel registrado no Brasil, em evidente reforço à publicidade registral.

A presença do princípio da publicidade em nosso direito privado, mais especificamente no direito de propriedade, figura como paradigma irrestrito e absoluto dos negócios envolvendo propriedade imóvel, o que remonta a Grécia Antiga. Pode-se afirmar, portanto, que temos um sistema registral imobiliário brasileiro em evolução, mas fincado no pilar da publicidade, que, como visto, possui origens nas democracias helênicas. E se conclui, ainda, que a publicidade imobiliária tem imbricada relação com a prosperidade da democracia brasileira, assim como foi o caso na Grécia, que depende diretamente da vitalidade e diversidade das relações privadas.

Pretender-se qualquer alteração no sistema vigente, de forma a restringir a publicidade nas transações envolvendo imóveis no Brasil, significaria retrocesso injustificado na segurança jurídica que deve envolver as atividades econômicas, bem como de nossa democracia e da isonomia que ela deve impor às relações sociais. 


\section{REFERÊNCIAS}

ARAÚJO FILHO, Clarindo Ferreira. Constitucionalização das atividades notarial e de registro e a relação entre o princípio da eficiência e a responsabilidade civil. Dissertação (Mestrado Acadêmico em Direito Constitucional). Instituto Brasiliense de Direito Público, Brasília: IBDP, 2011.

BEAUCHET, Ludovic. Histoire du droit privée de la République athénienne. v. 3. Paris: Librairie Marescq Ainé, 1897.

BRASIL. Constituição (1988). Constituição da República Federativa do Brasil. Brasília, DF: Senado Federal, 1988.

BRASIL. Lei Federal 6.015, de 31 de dezembro de 1973. Dispõe sobre os registros públicos, e dá outras providências.

CICERO, M. Tullius. The Orations of Marcus Tullius Cicero. London: Henry G. Bohn, 1856. DARESTE, Rodolphe. En Revue de Législation Ancienne et Moderne Francaise et Etrangère, $1870-1871$.

GERNET, Louis. Droit et société dans la Gréce Ancienne. Paris: Recueil Sirey, 1964.

GRAY, Kevin; GRAY, Susan. Elements of land law. 5. ed. London: OUP, 2008.

LAGO, Ivan Jacopetti do. História da publicidade imobiliária no Brasil. Dissertação (Mestrado em Direito) - Faculdade de Direito da Universidade de São Paulo. 133f. São Paulo, 2008.

LUZZATI, I. Della trascrizione: commento teorico-pratico al titolo XXII, libro III del códice civile italiano. v. 1, 4 ed. Turim: Utet, 1905, p. LIV.

PEREIRA, Lafayette. Direito das coisas. Rio de Janeiro: Freitas Bastos, 1956.

POZO, L. La propriedad inmueble y el registro de la propriedad en el Egipto faraónico. Madrid: Colégio de Registradores de la Propriedad y Mercantiles de Espana, s/d.

PRINGSHEIM, F. Le témoignage dans la Gréce el Rome archaïque. In: Rev. Int. Dr. Ant., tomo II, 1951.

THEMUDO, Tiago, PASCARELLI, Adriano. O princípio da publicidade e o problema da transmissão da propriedade no direito privado grego. Revista Jurídica da FA7. v. 14. n. 2, p. 31-41, 2017.

ZENOTH, C. Le contrat de vente en droit grec classique les obligations des parties. In: Rev. Int. Dr. Ant., tomo II, 1953.

Submetido em: 5 mar. 2020.

Aceito em: 27 out. 2020. 